\title{
Cellular and Molecular Mediators of Neuroinflammation in
}

\section{Alzheimer Disease}

\author{
Seung-Hoon Yang \\ Department of Medical Biotechnology, College of Life Science and Biotechnology, Dongguk University, Goyang, Korea
}

\begin{abstract}
Alzheimer disease $(\mathrm{AD})$ is a neurodegenerative disorder characterized by the loss of neuronal cells and the progressive decline of cognitive function. The major pathological culprit of $\mathrm{AD}$ is aggregation of amyloid- $\beta(\mathrm{A} \beta)$ and hyperphosphorylation of tau, eventually leading to progressive neuronal cell death and brain atrophy. However, the detailed molecular and cellular mechanisms underlying $\mathrm{AD}$ development as a result of neuronal cell death are little known. Although several hypotheses have been proposed regarding the development of $\mathrm{AD}$, increasingly many studies suggest that the pathological progress of $\mathrm{AD}$ is not restricted to neuronal components such as $A \beta$ and tau, but is also closely related to inflammatory responses in the brain. Abnormalities of $A \beta$ and tau cause activity of pattern recognition receptors on the brain's immune cells, including microglia and astrocytes, and trigger the innate immune system by releasing inflammatory mediators in the pathogenesis of $\mathrm{AD}$. In this review, we present a basic overview of the current knowledge regarding inflammation and molecular mediators in the pathological progress of $\mathrm{AD}$.
\end{abstract}

Keywords: Alzheimer disease; Neuroinflammation; Cellular mediators; Molecular mediators; Amyloid- $\beta$; Tau

- Fund/Grant Support: This research was supported by Basic Science Research Program through the National Research Foundation of Korea (NRF) funded by the Ministry of Education, Science and Technology (2015R1A6A3A04058568).

- Conflict of Interest: No potential conflict of interest relevant to this article was reported.

\section{INTRODUCTION}

Alzheimer disease (AD) is a neurodegenerative disease characterized by loss of neurons and synapses, leading to declines in learning and memory function in the brain $[1,2]$. The main hallmark of $\mathrm{AD}$ is the aggregation and deposition of amyloid- $\beta$ $(\mathrm{A} \beta)$ peptides on the extracellular surface of neuronal cells, leading to the formation of $A \beta$ oligomers and fibrils in the brain [3]. Another phenomenon observed in $\mathrm{AD}$ patients is hyperphosphorylation of tau protein in the brain, which accumulates in the microtubules of neurons and forms neurofibrillary tangles [4,5]. It is known that these 2 major hallmark features exert cytotoxic activities against neuronal cells, ultimately inducing the destruction of brain structure and memory decline [6,7].

Additionally, increasing evidence suggests that astrocytes and microglia are colocalized with $\mathrm{A} \beta$ plaques and neurofibrillary tangles in the brain of individuals with $\mathrm{AD}$ [8], implying that neuroinflammation may be a major component of $\mathrm{AD}$ pathogenesis. In epidemiological studies, $\mathrm{AD}$ patients who receive long-term treatment with an anti-inflammatory drug have shown diminished development of $\mathrm{AD}$. Moreover, the correlation between genes regulating the immune response and $\mathrm{AD}$ pathogenesis has been confirmed by genome-wide association studies [9-11]. During the progression of AD, astrocytes
Corresponding author: Seung-Hoon Yang (iD https://orcid.org/0000-0002-6880-8861 Department of Medical Biotechnology, College of Life Science and Biotechnology, Dongguk University, 32 Dongguk-ro, Ilsandong-gu, Goyang 10326, Korea E-mail: shyang@dongguk.edu / Tel: +82-31-961-5156 / Fax: +82-31-961-5108 Submitted: October 12, 2019 / Accepted after revision: November 14, 2019
cC (7) This is an Open Access article distributed under the terms of the Creative Commons Attribution Non-Commercial License (http://creativecommons.org/licenses/by-nc/4.0/) which permits unrestricted non-commercial use, distribution, and reproduction in any medium, provided the original work is properly cited. 


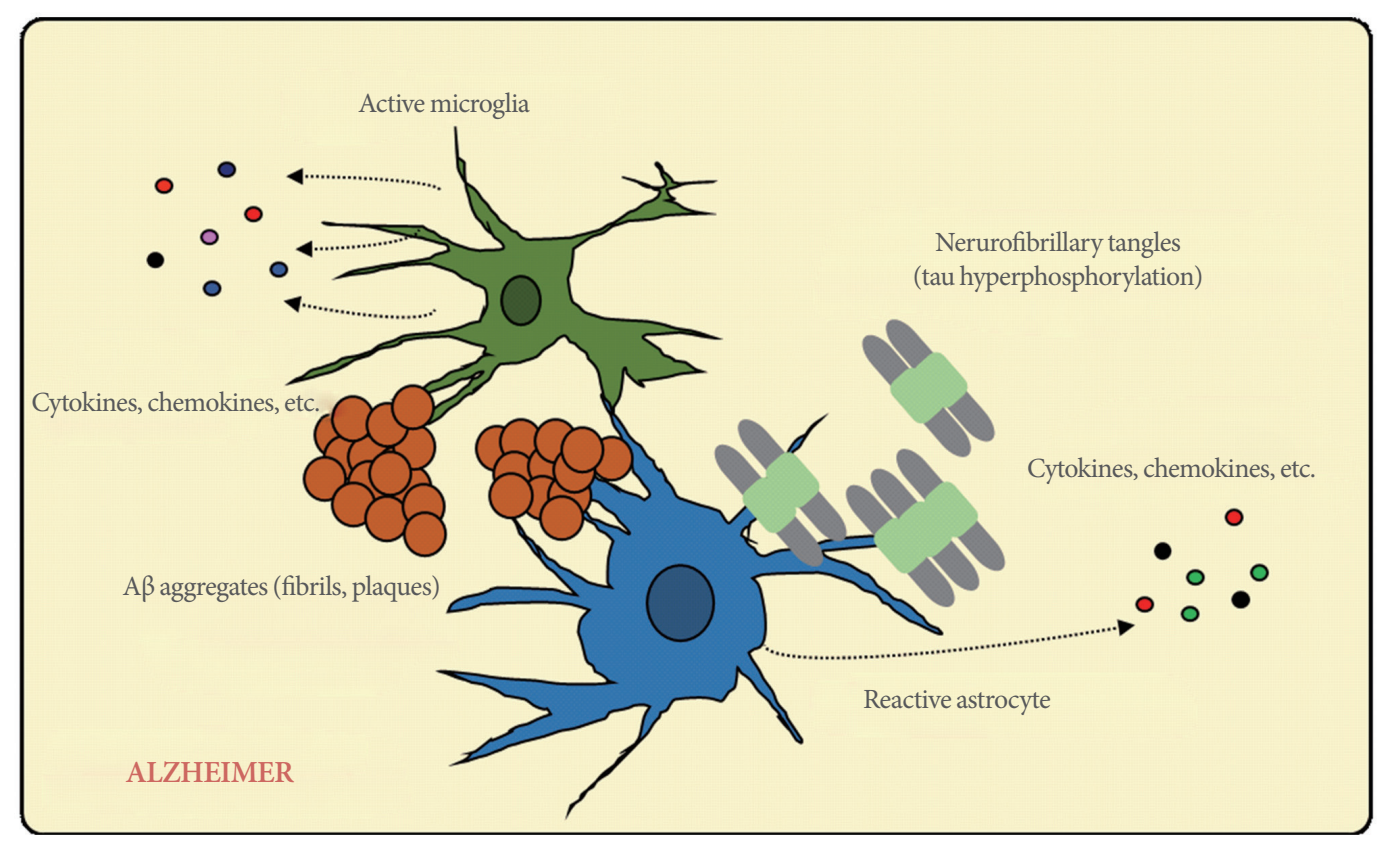

Fig. 1. Neuroinflammation during Alzheimer disease development. In the presence of amyloid- $\beta$ aggregates and neurofibrillary tangles, immune cells are activated and produce a variety of inflammatory mediators such as cytokines and chemokines.

and microglia are activated by the stimulation of $A \beta$ plaques and neurofibrillary tangles. Activated astrocytes and microglia then migrate and surround the plaque and tangles, releasing inflammation-associated proteins such as cytokines, chemokines, and other pro-inflammatory mediators in the brain (Fig. 1) $[12,13]$. However, the cellular and molecular mechanisms underlying neuroinflammation in $\mathrm{AD}$ are not fully understood. Therefore, understanding the mechanisms that regulate neuroinflammatory processes and their impact on $\mathrm{AD}$ processes is important for the development of new strategies for $\mathrm{AD}$ treatment.

\section{CELLULAR MEDIATORS OF NEUROINFLAMMATION IN AD}

\section{Microglia}

Microglia are the resident phagocytes of the brain, where they are ubiquitously present. They contribute to protection against infection by recognizing and responding to foreign antigens, while simultaneously supporting maintenance of the brain tissue [14]. To maintain these physiological functions, including microglial homeostasis, microglia express or release various molecules during brain development and in the normal adult central nervous system (CNS). In brain development, microglia regulate apoptosis of neuronal subpopulations by CD11b, triggering receptor expressed on myeloid cells 2 (TREM2), and DAP12; release neurotrophic factors such as brain-derived neurotrophic factor; and guide sprouting vessels. Microglia also contribute to maturation of the neuronal network and the maintenance of neuronal health by releasing CX3CR1 in the adult CNS [15].

Once activated by pathological triggers such as oxidative stress or misfolded protein aggregates, microglia begin to migrate to the locus of infection and initiate the innate immune response $[16,17]$. The initiation of the immune response by pathological triggers is mediated by receptor binding to pattern-associated molecular patterns or danger-associated molecular patterns. It has been suggested that the initial pathological trigger of microglial activation in $\mathrm{AD}$ is $\mathrm{A} \beta$ oligomers and fibrils, which are recognized by and bind with a variety of immune receptors including CD36, CD14, and toll-like receptors (TLR2, TLR4, TLR6, and TLR9) [18-21]. This binding of A $\beta$ with immune receptors results in microglial activation, which induces the release of several pro-inflammatory cytokines and chemokines. It has been shown that removal of the immune receptor gene $C D 36$ results in the reduction of $A \beta$-induced proinflammatory cytokine production and the prevention of intracellular $A \beta$ deposition $[22,23]$. $A \beta$ oligomers and fibrils are engulfed by the phagocytosis of activated microglia, and conse- 
quently undergo endosomal/lysosomal degradation processes for the clearance of $A \beta[24]$.

In animal models of early $\mathrm{AD}$ development, the immune response induces $A \beta$ clearance through the activation of microglia, indicating that the immune response favorably regulates AD-related pathologies [25-27]. However, chronic activation of the immune response by microglia results in an aggravation of $\mathrm{AD}$ pathologies, such as reactive microgliosis. The continuous activation results in sustained signaling transduction by pro-inflammatory cytokines, leading to neuronal damage and resulting in the loss of phagocytosis activity by microglia and diminished breakdown of $A \beta$ plaques $[28,29]$.

Further compelling evidence that compromised microglial function elevates the risk of $\mathrm{AD}$ through mis-regulation of the inflammatory response comes from studies identifying a rare mutation in the extracellular domain of TREM2 [30-32]. TREM2 is mainly expressed by the microglia and regulates the phagocytosis of $A \beta$. A rare mutation in TREM2 results in substantially increased $\mathrm{AD}$ risk [33-35] .

In the CNS of aging animals, microglial cells show an enhanced response to inflammatory triggers, similar to that observed in microglia in individuals with an ongoing neurodegenerative disorder [36,37]. Furthermore, microglia primarily have an immunomodulatory function and express many immune response-related antigens and molecules [38]. A recent study by Zare et al. [39] studied accumulation and effects of $A \beta$ itself, suggesting these changes may reach beyond the CNS. A transgenic mouse model showed $\mathrm{AD}$ mice had immunoreactivity against Alzheimer's disease markers in the bladder. These transgenic mice not only expressed $A \beta$ in the bladder, but also these changes were associated inducing voiding dysfunction independent of the CNS, possibly through peripheral neurogenic means. However, the detailed mechanism of microglial function within the CNS remains debatable. Given that microglial activation continuously occurs, inducing innate and adaptive immune responses in the brain, further research will be needed to define the roles of microglia during $\mathrm{AD}$ pathogenesis.

\section{Astrocytes}

Astrocytes are the predominant glial cells observed in the CNS and play major roles in neuroprotection, organization, and maintenance in the brain. They are involved in multiple processes in the CNS, including neurotransmitter secretion and metabolism, synaptic remodeling, modulation of stress, neural information processing, and neuronal signaling transduction
[40-42]. In early AD, similar to activated microglia, activated astrocytes are located around $A \beta$ plaques and accompany the phagocytosis and degradation of $A \beta$, suggesting that they play an important role in the clearance of aggregated and accumulated $\mathrm{A} \beta$ in brain tissue affected by $\mathrm{AD}$, along with microglia [13].

In $\mathrm{AD}$ animal models, the early response manifests by morphological changes including the atrophy of astrocytes, which may have functional consequences for synaptic connectivity. These changes have been shown to affect astrocytes located far from senile $A \beta$ plaques in the later phase of $A D$ progression [43-45]. Similar to microglia, astrocytes respond to fibrillar $A \beta$ aggregates, which are responsible for the activation of astrocytes in brain tissue affected by $\mathrm{AD}$. Reactive astrocytes then release many molecular mediators such as cytokines, nitric oxide, and other potentially toxic molecules, thereby enhancing the inflammatory response in the CNS. In an animal study, direct injection of $A \beta$ oligomers strongly induced a significant activation of astrocytes via activation of the nuclear factor-kappa $B$ (NF- $\mathrm{kB}$ ) transcription factor and production of inflammatory mediators such as tumor necrosis factor (TNF)- $\alpha$, interleukin (IL)- $1 \beta$, S100, and cyclooxygenase-2 (COX-2). By activating astrocytes, NF- $\kappa B$ signaling tightly regulates the production of cytokines and chemokines, leading to neurodegeneration [46].

\section{Oligodendrocytes}

Oligodendrocytes are crucial for neurotransmission and the maintenance of neuronal morphology. It also has been established that oligodendrocytes are involved in immunological reactions in other neurological diseases, particularly multiple sclerosis. However, little is known regarding the functions of oligodendrocytes in the progression of $\mathrm{AD}[47,48]$. A few studies have indicated that myelin abnormalities were found in the white matter of $\mathrm{AD}$ patients and that focal demyelination of axons was associated with $\mathrm{A} \beta$ aggregation in the gray matter of $\mathrm{AD}$ patients, as well as in the brains of $\mathrm{AD}$ transgenic mice $[48,49]$. Another study revealed that $A \beta$ injections induced microglial proliferation, with attenuated damage to myelin and a functional loss of oligodendrocytes [50]. In an in vitro analysis, several types of $A \beta$ peptides, such as $A \beta$ (25-35), $A \beta(1-40)$, and $A \beta$ (1-42) induced cytotoxic effects on the oligodendrocytes $[48,51,52]$. It was also suggested that the differentiation and function of oligodendrocytes are affected by the $P S 1_{\mathrm{M} 146 \mathrm{~V}}$ mutation and $\mathrm{A} \beta$ deposition [53].

Finally, oligodendrocytes express mRNA of complement components such as C1q, C1s, C2, C3, C4, C5, C6, C8, and C9, leading to a complement-associated immune response in 
pathologically susceptible lesions of brain tissue affected by $\mathrm{AD}$ [54]. Therefore, complement-activated oligodendrocytes may an important target cell type in $\mathrm{AD}$ patients in whom inflammatory responses have been observed.

\section{MOLECULAR MEDIATORS OF NEUROINFLAMMATION IN AD}

\section{Complement System}

The complement system is an essential mechanism of the innate and adaptive immune response against pathogens. This system consists of cell surface proteins and proteases that are cleaved and activated in a cascade [55]. The complement system is di- vided into 3 pathways: (1) the classical pathway induced by the binding of antibody isotypes bound to antigens, (2) the alternative pathway induced by the binding of microbial cell surfaces in the absence of antibodies, and (3) the lectin pathway induced by the binding of mannose-binding protein, which binds to surface carbohydrates on microbes. During early steps of complement activation, complement components are sequentially cleaved by C 3 convertase and $\mathrm{C} 5$ convertase in all 3 pathways. In the late steps of activation, $\mathrm{C} 5 \mathrm{~b}$ binds to $\mathrm{C} 6, \mathrm{C} 7, \mathrm{C} 8$, and $\mathrm{C} 9$ to form the membrane attack complex (Fig. 2) [56-59].

In studies of $\mathrm{AD}$, amyloid precursor protein (APP) transgenic mice in which $\mathrm{C} 3$ activation is inhibited have shown increased $A \beta$ accumulation. Consistent with this finding, in-

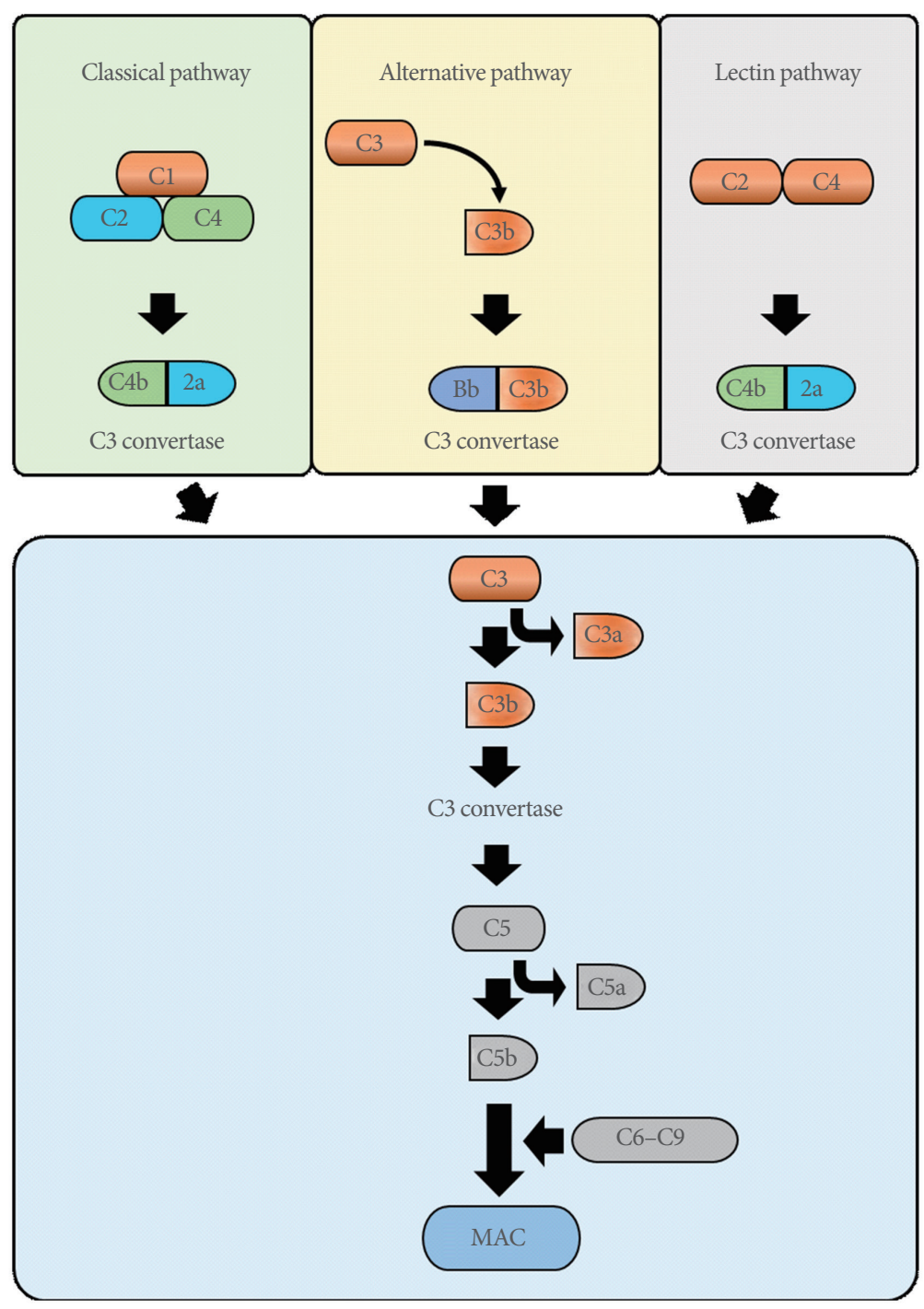

Fig. 2. Schematic overview of the 3 complement pathways. MAC, membrane attack complex. 
creased $A \beta$ deposition was observed in the brain of C3-deficient APP transgenic mice [25,60]. Moreover, activated complement components such as $\mathrm{C} 1 \mathrm{q}$ have been reported to recognize the aggregated forms of $A \beta$, but not the monomeric forms, in vitro. An $\mathrm{A} \beta$ aggregate bound to $\mathrm{C} 1 \mathrm{q}$ was found to be able to activate the alternative complement pathway, leading to processing and clearance of opsonized $A \beta[61,62]$. It appears that the activation of complement in $\mathrm{AD}$ might be effective for $\mathrm{A} \beta$ clearance; however, it also induces the production of neurotoxic materials by concomitant undesirable inflammation. Thus, additional studies will be required to provide convincing evidence of the function of the complement system in $\mathrm{AD}$ development.

\section{Cytokines}

Cytokines are mainly produced by microglia and astrocytes in the CNS and play a crucial role in the development of the CNS. Cytokines are involved in numerous inflammatory responses in neurodegenerative diseases [13]. Many studies of AD patients have revealed increased levels of pro-inflammatory cytokines, including TNF and IL $[63,64]$. In addition, several genetic investigations in mice showed that an elevated cytokine levels are significantly correlated with microglial activation and have effects on $A \beta$ generation, neurodegeneration, and cognition $[65,66]$.

First, TNF- $\alpha$ is one of the most important pro-inflammatory cytokines in $\mathrm{AD}$, having beneficial or harmful functions on different neurons. High levels of TNF- $\alpha$ have been reported in the brains of $\mathrm{AD}$ patients [67]. A $\beta$ directly stimulates TNF- $\alpha$ production from microglial cells through activation of the transcription factor NF- $\kappa B$ [68]. TNF- $\alpha$ also increases the expression of $\beta$ - and $\gamma$-secretase, an enzyme involved in the generation of $A \beta$ from APP in AD development $[69,70]$. In addition, mice lacking TNF receptor 1 crossed with the $\mathrm{AD}$ transgenic model showed reduced $A \beta$ aggregation and microglial activation, along with a recovery of cognitive function [71].

Second, IL-1 is a major pro-inflammatory cytokine that is expressed in the early stage of $\mathrm{A} \beta$ deposition during $\mathrm{AD}$ development [72]. IL-1 is produced by microglial cells surrounding A $\beta$ plaques and promotes the synthesis of S100, an inflammatory mediator, in astrocytes [73]. Within the IL-1 family, IL-1 $\beta$ production is strongly observed in the brain tissue of $\mathrm{AD}$ patients. IL- $1 \beta$ regulates the synthesis of APP, the secretion of APP from glial cells, and the amyloidogenic processing of APP [70]. Additionally, elevated levels of IL- $1 \beta$ in $\mathrm{AD}$ patients promote the activation of mitogen-activated protein kinase signaling, ultimately leading to the hyperphosphorylation of tau protein $[74,75]$.
Finally, IL-6 is important for the normal homeostasis of brain tissue. Inhibition of IL- 6 signaling promotes the reduction of microglial activation, while overexpression of IL-6 leads to chronic neuroinflammation [76]. In AD mouse models (TgCRND8 and Tg2576), overexpression of IL-6 in brain tissues has been observed [26]. Similar to IL-1 $\beta$, IL-6 is also produced by microglial cells and results in elevated mRNA levels of the APP gene [77]. IL-6 has also been reported to induce the hyperphosphorylation of tau protein by increasing the CDK5 activator p53, resulting in the formation of neurofibrillary tangles, which play an important role in $\mathrm{AD}$ pathology [78].

\section{Chemokines}

Chemokines are a family of chemoattractant small cytokines that are mainly produced by astrocytes and microglia to regulate their migration to inflamed areas, enhancing neuroinflammation in $\mathrm{AD}$ development $[79,80]$. Significant changes in chemokines and their receptors are observed in the blood plasma, cerebrospinal fluid (CSF), and brain tissue of $\mathrm{AD}$ patients compared with otherwise healthy individuals $[81,82]$. It has been reported that most chemokines and their receptors contribute to the neuroinflammation involved in $\mathrm{AD}$ by engaging peripheral monocytes and promoting the activation of glial cells such as microglia and astrocytes [82].

Evidence of the cooperative role of chemokines in $\mathrm{AD}$ has been provided by the observation of upregulation of the chemokine receptors CCR3 and CCR5 in reactive microglia surrounding senile $A \beta$ plaques $[83,84]$. A recent investigation of the CSF of $\mathrm{AD}$ patients revealed upregulation of CCL2, which was associated with cognitive decline [85]. Moreover, in vitro analyses have shown that $\mathrm{A} \beta$ promoted the generation of CXCR8, CCL2, CCL3, and CCL4 in astrocytes and microglia [86]. In $\mathrm{AD}$ mice, the neuronal death and cognition decline induced by $\mathrm{A} \beta$ deposition were found to be regulated by CX3CR1 and CX3CL1 [87-89]. Therefore, it has been suggested that in $\mathrm{AD}$, chemokines are able to promote central and peripheral immunity, which contributes to disease progression.

\section{Cyclooxygenases}

Given that inflammatory mediators are closely associated with the pathology of AD [72], epidemiological studies have suggested that nonsteroidal anti-inflammatory drugs (NSAIDs), which are major inhibitors of COX, may be promising for $\mathrm{AD}$ drug development [90]. COX is an enzyme that is responsible for converting arachidonic acid in the process of prostaglandin 
synthesis. There are 2 types of COX: COX-1 and COX-2. Whereas COX-1 is expressed in many cell types and is involved in the physiological production of prostanoids, COX-2 is produced during inflammation and results in pro-inflammatory prostanoid synthesis $[91,92]$. COX-1 and COX2 are differently expressed in various stages of $\mathrm{AD}$ pathology [90]. While COX1 is primary expressed in microglia, which are involved in $A \beta$ aggregates in the late stage of $\mathrm{AD}, \mathrm{COX}-2$ is highly expressed in neurons and is colocalized with the expression of cell cycle proteins under conditions of low $\mathrm{A} \beta$ deposits and tau tangles in the early stage of $\mathrm{AD}$.

In $\mathrm{AD}$ mice models, overexpression of COX-2 in neurons contributed to neuronal cell death by the formation of $A \beta$ plaques and by the production of free radicals, causing aggravated cognitive deficits. Furthermore, the appearance of neuronal death in AD was inhibited by treatment with NSAIDs [91-95]. Thus, many scientists have suggested that drug development using NSAIDs to target COX-mediated neuronal cell death may be a promising potential strategy for the treatment of $\mathrm{AD}$.

\section{CONCLUSIONS}

Here, we investigated neuroinflammation and consequent inflammatory mediators (cellular and molecular) in the pathological progress of $\mathrm{AD}$. Inflammation is not only found in many tissues and lymphoid organs, but is also observed in neurodegenerative diseases such as $\mathrm{AD}$. Many scientists have proposed that inflammation occurs in the presence of misfolded $A \beta$ and tau proteins, resulting in initiation or acceleration of the development of the disease. However, other investigators have argued that inflammation might be a beneficial defense mechanism against neurotoxicity in brain tissue affected by $\mathrm{AD}$. Whether inflammation promotes or alleviates $\mathrm{AD}$, it should be acknowledged that neuroinflammation plays a major role in the development of $\mathrm{AD}$. Therefore, additional studies should be conducted to define the detailed molecular mechanisms and crosstalk between neuroinflammation and AD. Therapeutic approaches targeting and regulating neuroinflammation will be a promising frontier in terms of new treatments for $\mathrm{AD}$.

\section{REFERENCES}

1. Alzheimer's Association. 2012 Alzheimer's disease facts and figures. Alzheimers Dement 2012;8:131-68.

2. Brookmeyer R, Johnson E, Ziegler-Graham K, Arrighi HM. Fore- casting the global burden of Alzheimer's disease. Alzheimers Dement 2007;3:186-91.

3. Jin M, Shepardson N, Yang T, Chen G, Walsh D, Selkoe DJ. Soluble amyloid beta-protein dimers isolated from Alzheimer cortex directly induce Tau hyperphosphorylation and neuritic degeneration. Proc Natl Acad Sci U S A 2011;108:5819-24.

4. Schoonenboom NS, Pijnenburg YA, Mulder C, Rosso SM, Van Elk EJ, Van Kamp GJ, et al. Amyloid beta(1-42) and phosphorylated tau in CSF as markers for early-onset Alzheimer disease. Neurology 2004;62:1580-4.

5. Sobow T, Flirski M, Liberski PP. Amyloid-beta and tau proteins as biochemical markers of Alzheimer's disease. Acta Neurobiol Exp (Wars) 2004;64:53-70.

6. Gong CX, Iqbal K. Hyperphosphorylation of microtubule-associated protein tau: a promising therapeutic target for Alzheimer disease. Curr Med Chem 2008;15:2321-8.

7. Fischer P, Zehetmayer S, Jungwirth S, Weissgram S, Krampla W, Hinterberger M, et al. Risk factors for Alzheimer dementia in a community-based birth cohort at the age of 75 years. Dement Geriatr Cogn Disord 2008;25:501-7.

8. Serrano-Pozo A, Mielke ML, Gomez-Isla T, Betensky RA, Growdon $\mathrm{JH}$, Frosch MP, et al. Reactive glia not only associates with plaques but also parallels tangles in Alzheimer's disease. Am J Pathol 2011; 179:1373-84.

9. Bu XL, Yao XQ, Jiao SS, Zeng F, Liu YH, Xiang Y, et al. A study on the association between infectious burden and Alzheimer's disease. Eur J Neurol 2015;22:1519-25.

10. Budni J, Garcez ML, de Medeiros J, Cassaro E, Bellettini-Santos T, Mina F, et al. The anti-inflammatory role of minocycline in Alzheimer's disease. Curr Alzheimer Res 2016;13:1319-29.

11. Lambert JC, Ibrahim-Verbaas CA, Harold D, Naj AC, Sims R, Bellenguez $\mathrm{C}$, et al. Meta-analysis of 74,046 individuals identifies 11 new susceptibility loci for Alzheimer's disease. Nat Genet 2013; 45:1452-8.

12. Iversen LL, Mortishire-Smith RJ, Pollack SJ, Shearman MS. The toxicity in vitro of beta-amyloid protein. Biochem J 1995;311(Pt 1): 1-16.

13. Meraz-Rios MA, Toral-Rios D, Franco-Bocanegra D, Villeda-Hernandez J, Campos-Pena V. Inflammatory process in Alzheimer's disease. Front Integr Neurosci 2013;7:59.

14. Kettenmann H, Hanisch UK, Noda M, Verkhratsky A. Physiology of microglia. Physiol Rev 2011;91:461-553.

15. Kierdorf K, Prinz M. Microglia in steady state. J Clin Invest 2017; 127:3201-9.

16. Heneka MT, Carson MJ, El Khoury J, Landreth GE, Brosseron F, 
Feinstein DL, et al. Neuroinflammation in Alzheimer's disease. Lancet Neurol 2015;14:388-405.

17. Ji K, Akgul G, Wollmuth LP, Tsirka SE. Microglia actively regulate the number of functional synapses. PLoS One 2013;8:e56293.

18. Bamberger ME, Harris ME, McDonald DR, Husemann J, Landreth GE. A cell surface receptor complex for fibrillar beta-amyloid mediates microglial activation. J Neurosci 2003;23:2665-74.

19. Paresce DM, Ghosh RN, Maxfield FR. Microglial cells internalize aggregates of the Alzheimer's disease amyloid beta-protein via a scavenger receptor. Neuron 1996;17:553-65.

20. Stewart CR, Stuart LM, Wilkinson K, van Gils JM, Deng J, Halle A, et al. CD36 ligands promote sterile inflammation through assembly of a Toll-like receptor 4 and 6 heterodimer. Nat Immunol 2010; 11:155-61.

21. Liu Y, Walter S, Stagi M, Cherny D, Letiembre M, Schulz-Schaeffer $\mathrm{W}$, et al. LPS receptor (CD14): a receptor for phagocytosis of $\mathrm{Al}-$ zheimer's amyloid peptide. Brain 2005;128(Pt 8):1778-89.

22. El Khoury JB, Moore KJ, Means TK, Leung J, Terada K, Toft M, et al. CD36 mediates the innate host response to beta-amyloid. J Exp Med 2003;197:1657-66.

23. Sheedy FJ, Grebe A, Rayner KJ, Kalantari P, Ramkhelawon B, Carpenter SB, et al. CD36 coordinates NLRP3 inflammasome activation by facilitating intracellular nucleation of soluble ligands into particulate ligands in sterile inflammation. Nat Immunol 2013;14: 812-20.

24. Lee CY, Landreth GE. The role of microglia in amyloid clearance from the AD brain. J Neural Transm (Vienna) 2010;117:949-60.

25. Wyss-Coray T, Yan F, Lin AH, Lambris JD, Alexander JJ, Quigg RJ, et al. Prominent neurodegeneration and increased plaque formation in complement-inhibited Alzheimer's mice. Proc Natl Acad Sci U S A 2002;99:10837-42.

26. Chakrabarty P, Jansen-West K, Beccard A, Ceballos-Diaz C, Levites Y, Verbeeck C, et al. Massive gliosis induced by interleukin- 6 suppresses Abeta deposition in vivo: evidence against inflammation as a driving force for amyloid deposition. FASEB J 2010;24:548-59.

27. Shaftel SS, Kyrkanides S, Olschowka JA, Miller JN, Johnson RE, O'Banion MK. Sustained hippocampal IL-1 beta overexpression mediates chronic neuroinflammation and ameliorates Alzheimer plaque pathology. J Clin Invest 2007;117:1595-604.

28. Hickman SE, Allison EK, El Khoury J. Microglial dysfunction and defective beta-amyloid clearance pathways in aging Alzheimer's disease mice. J Neurosci 2008;28:8354-60.

29. Meda L, Cassatella MA, Szendrei GI, Otvos L Jr, Baron P, Villalba $\mathrm{M}$, et al. Activation of microglial cells by beta-amyloid protein and interferon-gamma. Nature 1995;374:647-50.
30. Jay TR, Miller CM, Cheng PJ, Graham LC, Bemiller S, Broihier ML, et al. TREM2 deficiency eliminates TREM2+ inflammatory macrophages and ameliorates pathology in Alzheimer's disease mouse models. J Exp Med 2015;212:287-95.

31. Bemiller SM, McCray TJ, Allan K, Formica SV, Xu G, Wilson G, et al. TREM2 deficiency exacerbates tau pathology through dysregulated kinase signaling in a mouse model of tauopathy. Mol Neurodegener 2017;12:74.

32. Savage JC, Jay T, Goduni E, Quigley C, Mariani MM, Malm T, et al. Nuclear receptors license phagocytosis by trem2+ myeloid cells in mouse models of Alzheimer's disease. J Neurosci 2015;35:6532-43.

33. Guerreiro R, Wojtas A, Bras J, Carrasquillo M, Rogaeva E, Majounie E, et al. TREM2 variants in Alzheimer's disease. $\mathrm{N}$ Engl J Med 2013;368:117-27.

34. Hickman SE, El Khoury J. TREM2 and the neuroimmunology of Alzheimer's disease. Biochem Pharmacol 2014;88:495-8.

35. Jin SC, Carrasquillo MM, Benitez BA, Skorupa T, Carrell D, Patel $\mathrm{D}$, et al. TREM2 is associated with increased risk for Alzheimer's disease in African Americans. Mol Neurodegener 2015;10:19.

36. Perry VH, Teeling J. Microglia and macrophages of the central nervous system: the contribution of microglia priming and systemic inflammation to chronic neurodegeneration. Semin Immunopathol 2013;35:601-12.

37. Boche D, Perry VH, Nicoll JA. Review: activation patterns of microglia and their identification in the human brain. Neuropathol Appl Neurobiol 2013;39:3-18.

38. Town T, Nikolic V, Tan J. The microglial "activation" continuum: from innate to adaptive responses. J Neuroinflammation 2005;2:24.

39. Zare A. Unveiling the sensory connections between the bladder and the brain that involve the periaqueductal gray matter [dissertation]. Maastricht (Netherlands): Maastricht University; 2018. https://doi.org/10.26481/dis.20180619az.

40. Halassa MM, Haydon PG. Integrated brain circuits: astrocytic networks modulate neuronal activity and behavior. Annu Rev Physiol 2010;72:335-55.

41. Sofroniew MV, Vinters HV. Astrocytes: biology and pathology. Acta Neuropathol 2010;119:7-35.

42. Henneberger C, Papouin T, Oliet SH, Rusakov DA. Long-term potentiation depends on release of $\mathrm{D}$-serine from astrocytes. Nature 2010;463:232-6.

43. Olabarria M, Noristani HN, Verkhratsky A, Rodriguez JJ. Concomitant astroglial atrophy and astrogliosis in a triple transgenic animal model of Alzheimer's disease. Glia 2010;58:831-8.

44. Olabarria M, Noristani HN, Verkhratsky A, Rodriguez JJ. Age-dependent decrease in glutamine synthetase expression in the hippo- 
campal astroglia of the triple transgenic Alzheimer's disease mouse model: mechanism for deficient glutamatergic transmission? Mol Neurodegener 2011;6:55.

45. Yeh CY, Vadhwana B, Verkhratsky A, Rodriguez JJ. Early astrocytic atrophy in the entorhinal cortex of a triple transgenic animal model of Alzheimer's disease. ASN Neuro 2011;3:271-9.

46. Carrero I, Gonzalo MR, Martin B, Sanz-Anquela JM, Arevalo-Serrano J, Gonzalo-Ruiz A. Oligomers of beta-amyloid protein (Abeta1-42) induce the activation of cyclooxygenase- 2 in astrocytes via an interaction with interleukin-1beta, tumour necrosis factor-alpha, and a nuclear factor kappa-B mechanism in the rat brain. Exp Neurol 2012;236:215-27.

47. Kobayashi K, Hayashi M, Nakano H, Fukutani Y, Sasaki K, Shimazaki M, et al. Apoptosis of astrocytes with enhanced lysosomal activity and oligodendrocytes in white matter lesions in Alzheimer's disease. Neuropathol Appl Neurobiol 2002;28:238-51.

48. Roth AD, Ramirez G, Alarcon R, Von Bernhardi R. Oligodendrocytes damage in Alzheimer's disease: beta amyloid toxicity and inflammation. Biol Res 2005;38:381-7.

49. Mitew S, Kirkcaldie MT, Halliday GM, Shepherd CE, Vickers JC, Dickson TC. Focal demyelination in Alzheimer's disease and transgenic mouse models. Acta Neuropathol 2010;119:567-77.

50. Jantaratnotai N, Ryu JK, Kim SU, McLarnon JG. Amyloid beta peptide-induced corpus callosum damage and glial activation in vivo. Neuroreport 2003;14:1429-33.

51. Xu J, Chen S, Ahmed SH, Chen H, Ku G, Goldberg MP, et al. Amyloid-beta peptides are cytotoxic to oligodendrocytes. J Neurosci 2001;21:RC118.

52. Lee JT, Xu J, Lee JM, Ku G, Han X, Yang DI, et al. Amyloid-beta peptide induces oligodendrocyte death by activating the neutral sphingomyelinase-ceramide pathway. J Cell Biol 2004;164:123-31.

53. Desai MK, Guercio BJ, Narrow WC, Bowers WJ. An Alzheimer's disease-relevant presenilin-1 mutation augments amyloid-beta-induced oligodendrocyte dysfunction. Glia 2011;59:627-40.

54. Hosokawa M, Klegeris A, Maguire J, McGeer PL. Expression of complement messenger RNAs and proteins by human oligodendroglial cells. Glia 2003;42:417-23.

55. Forneris F, Wu J, Gros P. The modular serine proteases of the complement cascade. Curr Opin Struct Biol 2012;22:333-41.

56. Noris M, Remuzzi G. Overview of complement activation and regulation. Semin Nephrol 2013;33:479-92.

57. Gasque P, Singhrao SK, Neal JW, Wang P, Sayah S, Fontaine M, et al. The receptor for complement anaphylatoxin C3a is expressed by myeloid cells and nonmyeloid cells in inflamed human central nervous system: analysis in multiple sclerosis and bacterial meningitis.
J Immunol 1998;160:3543-54.

58. Gasque P, Ischenko A, Legoedec J, Mauger C, Schouft MT, Fontaine M. Expression of the complement classical pathway by human glioma in culture. A model for complement expression by nerve cells. J Biol Chem 1993;268:25068-74.

59. Ricklin D, Hajishengallis G, Yang K, Lambris JD. Complement: a key system for immune surveillance and homeostasis. Nat Immunol 2010;11:785-97.

60. Maier M, Peng Y, Jiang L, Seabrook TJ, Carroll MC, Lemere CA. Complement $\mathrm{C} 3$ deficiency leads to accelerated amyloid beta plaque deposition and neurodegeneration and modulation of the microglia/macrophage phenotype in amyloid precursor protein transgenic mice. J Neurosci 2008;28:6333-41.

61. Webster SD, Yang AJ, Margol L, Garzon-Rodriguez W, Glabe CG, Tenner AJ. Complement component Clq modulates the phagocytosis of Abeta by microglia. Exp Neurol 2000;161:127-38.

62. Fonseca MI, Zhou J, Botto M, Tenner AJ. Absence of C1q leads to less neuropathology in transgenic mouse models of Alzheimer's disease. J Neurosci 2004;24:6457-65.

63. Blum-Degen D, Muller T, Kuhn W, Gerlach M, Przuntek H, Riederer P. Interleukin- 1 beta and interleukin- 6 are elevated in the cerebrospinal fluid of Alzheimer's and de novo Parkinson's disease patients. Neurosci Lett 1995;202:17-20.

64. Jiang H, Hampel H, Prvulovic D, Wallin A, Blennow K, Li R, et al. Elevated CSF levels of TACE activity and soluble TNF receptors in subjects with mild cognitive impairment and patients with $\mathrm{Al}-$ zheimer's disease. Mol Neurodegener 2011;6:69.

65. Meda L, Baron P, Prat E, Scarpini E, Scarlato G, Cassatella MA, et al. Proinflammatory profile of cytokine production by human monocytes and murine microglia stimulated with beta-amyloid[25-35]. J Neuroimmunol 1999;93:45-52.

66. Patel NS, Paris D, Mathura V, Quadros AN, Crawford FC, Mullan MJ. Inflammatory cytokine levels correlate with amyloid load in transgenic mouse models of Alzheimer's disease. J Neuroinflammation 2005;2:9.

67. Chang R, Yee KL, Sumbria RK. Tumor necrosis factor alpha Inhibition for Alzheimer's Disease. J Cent Nerv Syst Dis 2017;9:1179573517709278.

68. Combs CK, Karlo JC, Kao SC, Landreth GE. Beta-amyloid stimulation of microglia and monocytes results in TNFalpha-dependent expression of inducible nitric oxide synthase and neuronal apoptosis. J Neurosci 2001;21:1179-88.

69. Blasko I, Veerhuis R, Stampfer-Kountchev M, Saurwein-Teissl M, Eikelenboom P, Grubeck-Loebenstein B. Costimulatory effects of interferon-gamma and interleukin-lbeta or tumor necrosis factor alpha on the synthesis of Abeta1-40 and Abeta1- 42 by human as- 
trocytes. Neurobiol Dis 2000;7(6 Pt B):682-9.

70. Liao YF, Wang BJ, Cheng HT, Kuo LH, Wolfe MS. Tumor necrosis factor-alpha, interleukin-1beta, and interferon-gamma stimulate gamma-secretase-mediated cleavage of amyloid precursor protein through a JNK-dependent MAPK pathway. J Biol Chem 2004; 279:49523-32.

71. He P, Zhong Z, Lindholm K, Berning L, Lee W, Lemere C, et al. Deletion of tumor necrosis factor death receptor inhibits amyloid beta generation and prevents learning and memory deficits in $\mathrm{Al}$ zheimer's mice. J Cell Biol 2007;178:829-41.

72. Akiyama H, Barger S, Barnum S, Bradt B, Bauer J, Cole GM, et al. Inflammation and Alzheimer's disease. Neurobiol Aging 2000;21: 383-421.

73. Griffin WS, Stanley LC, Ling C, White L, MacLeod V, Perrot LJ, et al. Brain interleukin 1 and S-100 immunoreactivity are elevated in Down syndrome and Alzheimer disease. Proc Natl Acad Sci U S A 1989;86:7611-5.

74. Sheng JG, Zhu SG, Jones RA, Griffin WS, Mrak RE. Interleukin-1 promotes expression and phosphorylation of neurofilament and tau proteins in vivo. Exp Neurol 2000;163:388-91.

75. Li Y, Liu L, Barger SW, Griffin WS. Interleukin-1 mediates pathological effects of microglia on tau phosphorylation and on synaptophysin synthesis in cortical neurons through a p38-MAPK pathway. J Neurosci 2003;23:1605-11.

76. Rothaug M, Becker-Pauly C, Rose-John S. The role of interleukin-6 signaling in nervous tissue. Biochim Biophys Acta 2016;1863(6 Pt A):1218-27.

77. Ringheim GE, Szczepanik AM, Petko W, Burgher KL, Zhu SZ, Chao CC. Enhancement of beta-amyloid precursor protein transcription and expression by the soluble interleukin- 6 receptor/interleukin-6 complex. Brain Res Mol Brain Res 1998;55:35-44.

78. Quintanilla RA, Orellana DI, Gonzalez-Billault C, Maccioni RB. Interleukin-6 induces Alzheimer-type phosphorylation of tau protein by deregulating the cdk5/p35 pathway. Exp Cell Res 2004;295: 245-57.

79. Cyster JG. Chemokines and cell migration in secondary lymphoid organs. Science 1999;286:2098-102.

80. Ransohoff RM. The chemokine system in neuroinflammation: an update. J Infect Dis 2002;186 Suppl 2:S152-6.

81. Liu C, Cui G, Zhu M, Kang X, Guo H. Neuroinflammation in Alzheimer's disease: chemokines produced by astrocytes and chemokine receptors. Int J Clin Exp Pathol 2014;7:8342-55.

82. Zuena AR, Casolini P, Lattanzi R, Maftei D. Chemokines in Alzheimer's disease: new insights into prokineticins, chemokine-like proteins. Front Pharmacol 2019;10:622.
83. Ishizuka K, Kimura T, Igata-yi R, Katsuragi S, Takamatsu J, Miyakawa T. Identification of monocyte chemoattractant protein-1 in senile plaques and reactive microglia of Alzheimer's disease. Psychiatry Clin Neurosci 1997;51:135-8.

84. Xia MQ, Qin SX, Wu LJ, Mackay CR, Hyman BT. Immunohistochemical study of the beta-chemokine receptors CCR3 and CCR5 and their ligands in normal and Alzheimer's disease brains. Am J Pathol 1998;153:31-7.

85. Westin K, Buchhave P, Nielsen H, Minthon L, Janciauskiene S, Hansson O. CCL2 is associated with a faster rate of cognitive decline during early stages of Alzheimer's disease. PLoS One 2012;7: e30525.

86. Smits HA, Rijsmus A, van Loon JH, Wat JW, Verhoef J, Boven LA, et al. Amyloid-beta-induced chemokine production in primary human macrophages and astrocytes. J Neuroimmunol 2002;127: 160-8.

87. Fuhrmann M, Bittner T, Jung CK, Burgold S, Page RM, Mitteregger $\mathrm{G}$, et al. Microglial Cx3cr1 knockout prevents neuron loss in a mouse model of Alzheimer's disease. Nat Neurosci 2010;13:411-3.

88. Lee S, Varvel NH, Konerth ME, Xu G, Cardona AE, Ransohoff $\mathrm{RM}$, et al. CX3CR1 deficiency alters microglial activation and reduces beta-amyloid deposition in two Alzheimer's disease mouse models. Am J Pathol 2010;177:2549-62.

89. Cho SH, Sun B, Zhou Y, Kauppinen TM, Halabisky B, Wes P, et al. CX3CR1 protein signaling modulates microglial activation and protects against plaque-independent cognitive deficits in a mouse model of Alzheimer disease. J Biol Chem 2011;286:32713-22.

90. Hoozemans JJ, Rozemuller JM, van Haastert ES, Veerhuis R, Eikelenboom P. Cyclooxygenase-1 and -2 in the different stages of Alzheimer's disease pathology. Curr Pharm Des 2008;14:1419-27.

91. Smith WL, DeWitt DL, Garavito RM. Cyclooxygenases: structural, cellular, and molecular biology. Annu Rev Biochem 2000;69:14582.

92. Warner TD, Mitchell JA. Cyclooxygenases: new forms, new inhibitors, and lessons from the clinic. FASEB J 2004;18:790-804.

93. Xiang Z, Ho L, Yemul S, Zhao Z, Qing W, Pompl P, et al. Cyclooxygenase- 2 promotes amyloid plaque deposition in a mouse model of Alzheimer's disease neuropathology. Gene Expr 2002;10:271-8.

94. Xiang Z, Ho L, Valdellon J, Borchelt D, Kelley K, Spielman L, et al. Cyclooxygenase (COX)-2 and cell cycle activity in a transgenic mouse model of Alzheimer's disease neuropathology. Neurobiol Aging 2002;23:327-34.

95. Pasinetti GM. Cyclooxygenase and inflammation in Alzheimer's disease: experimental approaches and clinical interventions. J Neurosci Res 1998;54:1-6. 